\title{
Learner Differences among Children Learning a Foreign Language: Language Anxiety, Strategy Use, and Multiple Intelligences
}

\author{
Hui-ju Liu ${ }^{1} \&$ Ting-Han Chen ${ }^{2}$ \\ ${ }^{1}$ Department of English, Da-Yeh University, Taiwan \\ ${ }^{2}$ Chung Kong Primary School, Taichung, Taiwan \\ Correspondence: Hui-ju Liu, Department of English, Da-Yeh University, Taiwan. E-mail: \\ carlota@mail.dyu.edu.tw
}

Received: March 10, 2014 Accepted: April 11, 2014 Online Published: May 14, 2014

doi:10.5539/elt.v7n6p1 URL: http://dx.doi.org/10.5539/elt.v7n6p1

\begin{abstract}
This study mainly investigates language anxiety and its relationship to the use of learning strategies and multiple intelligences among young learners in an EFL educational context. The participants were composed of 212 fifthand sixth-graders from elementary schools in central Taiwan. Findings indicated that most participants generally experienced a mild level of anxiety in the EFL classroom. However, at least a quarter of the full sample experienced an above-average level of anxiety when learning the target language. These students tended to be most anxious when (1) feeling that other students had better English performance, (2) being called on to speak in the English class, and (3) feeling afraid of being left behind in the English class. Overall, students were most likely to feel anxious due to worry over inadequate language performance and fear of being evaluated negatively by others. Furthermore, the current findings indicated a significant negative correlation between language anxiety and strategy use among the young EFL children. Students who had greater strategy use were less likely to feel anxiety. Interestingly, the use of social strategies had the strongest relationship with language anxiety among the young learners. Another learner variable, multiple intelligences, was found to be significantly related to both strategy use and anxiety; its relationship with strategy use seemed to be much stronger than that with anxiety. All six strategy categories were found to have significant correlations with multiple intelligences. Implications derived from the results are discussed in the paper.
\end{abstract}

Keywords: language learning strategies, strategy use, language anxiety

\section{Introduction}

English is learned as a foreign language (EFL) in Taiwan, but due to the limited opportunities to practice or use it in an everyday life environment, it is not easy for students to make any distinguishable improvement unless they are very enthusiastic and active learners. When learning in this EFL environment, students are very likely to experience a certain level of language anxiety, which has been found to have some damaging effect on language learning acquisition (Chen \& Chang, 2004; Cheng, 2005). There are, however, language learning strategies that are specific and conscious behaviors students can employ to achieve their goals in the language learning process (Oxford, 2003). The use of learning strategies has been found to be positively related to learning proficiency in prior research (Bremner, 1998; Lai, 2009; Peacock \& Ho, 2003; Wharton, 2000). Many researchers, such as Lai (2009), Sheu (2009), and $\mathrm{Wu}$ (2008), have therefore carried out investigations to explore the strategy use of students in the Taiwanese setting. Researchers in this field generally intend to identify the strategies used by more successful students and hope that their findings may increase the strategy awareness of both teachers and students. The current study aims to add to the understanding of the relation between learning strategy use and foreign language anxiety among the young learners in Taiwan. Another learner variable, which was found to be significantly related to strategy use (Akbari \& Hosseini, 2008) but rarely investigated in language learning research, multiple intelligences, has also been included in the present study and the relationships between the three variables are explored.

\subsection{Foreign Language Anxiety}

Language anxiety is defined by Gardner and MacIntyre (1993, p. 5) as "the apprehension experienced when a situation requires the use of a second language with which the individual is not fully proficient". The role of 
anxiety on language acquisition has been the central focus of research for about three decades. Prior research on language anxiety has consistently shown that this unique type of apprehension can exert debilitating effects on language learning (Aida, 1994; Cheng, 2005; Gardner, 1985; Kim, 2000; MacIntyre \& Gardner, 1991; Phillips, 1992). While many researchers have concerned themselves with the effects of anxiety on language acquisition, many others have attempted to identify the factors or sources of this affective variable (Vogely, 1998; Yan \& Horwitz, 2008; Young, 1991).

Young (1991) divided various potential sources of language anxiety into six categories: (1) personal and interpersonal anxieties, (2) learner beliefs about language learning, (3) instructor beliefs about language teaching, (4) instructor-learner interactions, (5) classroom procedures, and (6) language testing. These anxiety sources are associated with learners, instructors, or instructional practice, and may interact with one another to impede the acquisition of the target language. Young (1991) noted that perceived learner beliefs about language learning are likely to become a strong contributor to language anxiety. Similarly, Vogely (1998) categorized sources of anxiety related to listening comprehension into four types: (1) anxiety related to characteristics of language input (e.g., level of difficulty), (2) anxiety related to processing-related aspects of foreign language learning (e.g., inappropriate strategies), (3) anxiety related to instructional factors (e.g., uncomfortable environment), and (4) anxiety related to personal attributes of the teacher or learner (e.g., instructor's personality). Onwuegbuzie, Bailey, and Daley (1999) identified seven variables that can significantly predict foreign language anxiety: age, academic achievement, prior history of visiting foreign countries, prior high school experience with foreign languages, expectation of one's language achievement, perceived self-worth, and perceived academic competence. E. Horwitz, M. Horwitz, and Cope (1986), MacIntyre (1999), and Young (1990, 1991) suggested that certain unrealistic learner beliefs about language learning can also turn into a source of anxiety.

Horwitz et al. (1986) defined language anxiety as "a distinct complex of self-perceptions, beliefs, feelings, and behaviors related to classroom language learning arising from the uniqueness of the language learning process" (p. 128). They developed an instrument containing items reflective of anxiety in three aspects: communication apprehension, test anxiety, and fear of negative evaluation. Communication apprehension refers to frustration or worry due to the incapability either to understand others or to express oneself in a foreign language. Test anxiety is seen as a type of anxiety stemming from apprehension over one's test performance. Fear of negative evaluation refers to the apprehension about not being able to make a good impression in front of others when using a foreign language.

Chan and $\mathrm{Wu}$ (2004) examined foreign language anxiety among elementary school children in Taiwan and found that the children not only experienced language anxiety when learning English, but also had final scores that were negatively related to their scores on the anxiety scale. They further identified taking tests, speaking in front of others, speaking to native speakers, spelling, and incomprehensible input as the situations that were most likely to provoke anxiety among the young learners. As anxiety is shown to have a negative impact on language performance, it can also affect many other aspects of language learners, e.g., self-perceived competence (MacIntyre, 1999), self-confidence (Cheng et al., 1999), and perceived difficulty of a learning task (Saito, Horwitz, \& Garza, 1999). Many researchers have regarded anxiety as a construct that is complex and multifaceted (Cheng et al., 1999; Horwitz et al., 1986; Onwuegbuzie, Bailey, \& Daley, 1997, 1999; Young, 1991).

\subsection{Use of Language Learning Strategies}

Language learning strategies are defined as "specific actions or techniques that students use, often intentionally, to improve their progress in developing L2 skills" (Green \& Oxford, 1995, p. 262). Research on the use of language learning strategies has undergone tremendous growth over the paspt three decades (Chamot, 2005; Macaro, 2006). The application of learning strategies has been regarded as playing an essential role in the language acquisition process (Baker \& Boonkit, 2004). Oxford (1990) considered learning strategies to be "tools for active, self-directed involvement, which is essential for developing communicative competence" (p. 1); they are "problem-oriented," most often "conscious," and teachable (p. 9).

In Oxford's (1990) study, she not only noticed the major features of language learning strategies but also developed one of the most widely adopted instruments throughout the world, the Strategy Inventory for Language Learning (SILL). The 50-item SILL divided strategies into six categories: (1) memory (e.g., reviewing and making association), (2) cognitive (e.g., reasoning and analyzing), (3) compensation (e.g., guessing from the context), (4) metacognitive (e.g., planning and managing one's own learning), (5) affective (e.g., regulate one's own emotions), and (6) social strategies (e.g., asking for clarification) (Ehrman, Leaver, \& Oxford, 2003; Green \& Oxford, 1995). 
Over the past few decades, numerous studies have been exploring the relevance of language proficiency to the use of language learning strategies (Bremner, 1999; Green \& Oxford, 1995; Griffiths, 2003; Hong-Nam \& Leavell, 2006; Oxford \& Nyikos, 1989; Su, 2005; Wharton, 2000; Wu, 2008). All previous studies have suggested that highly proficient learners employ language learning strategies more frequently than those with lower proficiency; in addition, they were found to employ more varied language learning strategies (Green \& Oxford, 1995; Griffiths, 2003; Qingquan, Chatupote, \& Teo, 2008). However, there are inconsistent findings regarding the more frequently used types of strategies. For example, while Liu and Chang (2013) and Sheu (2009) found compensation strategies to be the most frequently used strategy type by Taiwanese EFL learners, Park (1997) and Goh and Foong (1997) found metacognitive strategies to be the most preferred type of strategies among foreign language learners in Korea and Singapore, respectively. Even in the same Taiwanese educational context, social strategies were reported to be the most frequently used strategies in Su's (2005) study.

Much research in this area has also investigated the relationships between language learning strategy use and other important learner factors, such as gender (Green \& Oxford, 1995; Hong-Nam \& Leavell, 2006), learning style (Ehrman \& Oxford, 1990; Oxford \& Anderson, 1995; Reid, 1987), cultural background (Littlewood, 2001; Oxford, 1990; Park, 1999; Peacock \& Ho, 2003; Reid, 1987), self-perceived proficiency (Liu, 2013; Su, 2005; Wharton, 2000), and motivation (Gardner, 2000; Gardner \& MacIntyre, 1991; Oxford \& Nyikos, 1989). It is not surprising that varied learner variables might influence a learner's choice of language learning strategies.

\subsection{Language Learning Strategy Use among Taiwanese Students}

As pointed out by Chamot and El-Dinary (1999), children have the ability to understand and employ language learning strategies. When Su (2003) investigated 932 elementary school students from grades 5 and 6 , she reported that six subcategories of learning strategies were moderately used and concluded that language learning experiences were related to language learning strategies. Variables related to language learning experiences included length of English study, years of studying English outside of school, and years of living in English-speaking countries. Lan (2005) also explored language learning strategy use (LLSU) among Taiwanese elementary school students and revealed that there were significant relationships between strategy use, gender, proficiency level, and degree of liking English.

Among EFL university students in Taiwan, compensation strategies were found by Liu and Chang (2013) to have the highest reported frequency, followed by metacognitive and cognitive strategies. Their study further revealed that academic self-concept, which is comprised of two components, academic self-confidence and learning effort, were significantly related to LLSU in all six categories, particularly metacognitive (.65) and cognitive (.65) strategy categories.

Unlike some findings by studies conducted on university students that reported compensation strategies as being the most frequently used strategy type (Lai, 2009; Liu \& Chang, 2013; Sheu, 2009; Wu, 2008), Su (2005) reported that social learning strategies were employed the most frequently and suggested that this may be due to the use and the impact of the Internet. In addition, self-perceived proficiency was found to have significant correlations with strategy use in all six categories, the highest correlation being with cognitive strategyies, followed by metacognitive strategies.

\subsection{The Theory of Multiple Intelligences}

Multiple intelligences (MI) were first proposed by Gardner (1983), who argued that the traditional notion of intelligence, which adopted a psychometric view and seemed to focus on language proficiency and math skills, lacked personal diversities and values. Instead of refining the one general intelligence, he proposed eight intelligences: bodily/kinesthetic, interpersonal/social, intrapersonal/introspective, logical/mathematical, musical/rhythmic, naturalist, verbal/linguistic, and visual/spatial. According to his theory, any learner can have these eight distinct intelligences which "can be developed throughout his or her lifetime" (Haley, 2004). One important aspect of the multiple intelligences theory is that various intelligences work at the same time instead of functioning independently. Over the past few decades, this theory has been successfully implemented in the classroom by many educators and teachers. MI-based instruction is more learner-centered and includes varied instructional activities to help learners achieve their highest potential (Haley, 2004). In order to help students learn and develop, teachers need to seriously take individual differences among their students into account. Campbell, Campbell, and Dickinson (1999) suggested that intelligences are means for problem-solving, learning, and creating that any learner can employ in class.

\subsection{Research Questions}

The deleterious influence of language anxiety on academic performance has been reported in many studies 
(Chen \& Chang, 2004; Cheng, 2005; MacIntyre \& Gardner, 1991; MacIntyre, Noels, \& Clément, 1997; Saito \& Samimy, 1996; Sparks \& Ganschow, 2001); nonetheless, there is rather limited research on the associations among anxiety, LLSU, and MI. As both LLSU and MI can have very positive effects on learning (Campbell et al., 1999; Oxford \& Ehrman, 1995), the purpose of the present study, therefore, is to gain a broader perspective on the relations between language anxiety and the two learner variables in the hopes that the findings can contribute to language instruction and research in this area. Statistical analyses are performed to investigate the following questions:

1) What is the broad profile of foreign language anxiety for the elementary school students?

2) What are the most often used types and frequency of LLSU by learners with varying levels of language anxiety?

3) Are there any significant relationships between anxiety, MI, LLSU, length of taking extracurricular English lessons, and length of English study?

4) Is it possible to use MI or anxiety as a predictor for LLSU?

\section{Method}

\subsection{Participants}

The participants in this study included 212 fifth and sixth-graders from central Taiwan, 119 males $(56.1 \%)$ and 93 females (43.9\%). About 75\% of the students had taken English lessons outside of the classroom. Table 1 presents the percentages of the young learners with varied lengths of extracurricular English study and total English study. It should be noted that 53 students did not provide information about how long they had taken extracurricular lessons.

Table 1. Percentages of students with various English learning experiences

\begin{tabular}{lcc}
\hline & $\begin{array}{c}\text { Length of Taking Extracurricular } \\
\text { English Lessons }\end{array}$ & Length of English Study \\
\hline Less than two years & 15.1 & 18.9 \\
2-4 years & 28.3 & 25.0 \\
5-7 years & 20.3 & 34.0 \\
Over 7 years & 11.3 & 17.9 \\
\hline
\end{tabular}

Note. The percentages do not add up to $100 \%$ because there are missing values.

\subsection{Instruments}

An instrument adapted from E. Horwitz, M. Horwitz, and Cope's (1986) Foreign Language Classroom Anxiety Scale (FLCAS) was used to measure language anxiety among the participants. The scale was modified and translated into a 29-item Chinese version to help the young Taiwanese students better understand the descriptions of the items. Four items from the original 33-item version were excluded since the statements may have been confusing to the 5th and 6th graders. For example, one item asks the students whether they feel nervous when speaking English with native speakers. However, some children, e.g., those who cannot afford to take extracurricular lessons, may never have had a chance to talk with a native speaker. The scale had items with a 6-point Likert-type response format ( $1=$ strongly disagree; $6=$ strongly agree), achieving an internal consistency of .94.

To investigate student strategy use, the instrument used was adapted from the Strategy Inventory for Language Learning (SILL) devised by Oxford (1990) and the Taiwanese Children's SILL developed by Lan and Oxford (2003). The items had a 5-point Likert-type response format $(1=$ never; $2=$ rarely; $3=$ sometimes; $4=$ often; $5=$ always). According to Oxford, the items measuring strategy use were classified into six categories: memory, cognitive, compensation, metacognitive, affective, and social strategies. The Cronbach's alpha for the modified Chinese version of the SILL was .95.

The scale used to measure multiple intelligences was adapted from the one used in Hsieh's (2001) research, which was based on Gardner's $(1983,1995)$ theory. It was also modified in the present study to enhance the understanding of each question by the young participants. Five of the nine subcategories of multiple intelligences in the original version, logical-mathematical, linguistic, interpersonal, intrapersonal, and visual-spatial, were selected because they relate more to language learning and may be more appropriate for the present study. The 
final questionnaire consisted of 39 items rated on six-point Likert scale and had a reliability of .93.

\subsection{Analysis of the Data}

Before any statistical analyses were conducted, the reverse worded items in the anxiety scale were recoded. Based on their total scores on the scale, participants were classified into three anxiety levels. A one-way ANOVA was conducted to confirm the significant differences in anxiety between the groups, after which the means of the item scores for each anxiety level were calculated and examined. To understand the types and frequency of strategy use by students across anxiety levels, the means of the six strategy-category scores were computed and examined. The relationships between the major variables in the study, i.e., LLSU, anxiety, MI, and two other learner experience related variables (length of taking extracurricular English lessons and length of English study), were then explored by computing Pearson product-moment correlation coefficients for each pair of the variables. Finally, a stepwise multiple regression analysis was performed with the total LLSU scores as the criterion variable and both language anxiety and MI as the predictor variables.

\section{Results and Discussion}

To examine the general profile of their language learning anxiety, students were first classified into three levels according to their overall anxiety scores. The students who scored at or below the 25 th percentile of the full sample's score distribution were classified into the low-anxiety group. In contrast, those who scored at or above the 75th percentile were assigned into the high-anxiety group. Table 2 presents the score distributions and percentages of the participants at each anxiety level. To confirm significant differences between the three anxiety groups, a one-way ANOVA was performed and the results of the analysis are presented in Table 3. As shown in the table, the scores of the three anxiety levels were significantly different, with a higher score indicating a significantly higher level of anxiety.

Table 2. Descriptive statistics of participants with different anxiety levels

\begin{tabular}{lccccc}
\hline Level & Number & Range of Scores & Percentage & Mean & SD \\
\hline Low-Anxiety & 50 & $29-70$ & 23.6 & 56.44 & 10.33 \\
Medium-Anxiety & 106 & $71-122$ & 50.0 & 99.67 & 13.73 \\
High-Anxiety & 56 & $123-174$ & 26.4 & 139.46 & 13.52 \\
\hline
\end{tabular}

Table 3. Analysis of variance results for language anxiety in three different levels

\begin{tabular}{lccccc}
\hline & Sum of Squares & df & Mean Square & $F$ & Sig. \\
\hline Between Groups & 182101.27 & 2 & 91050.63 & 542.34 & $.000 * *$ \\
Within Groups & 35087.69 & 209 & 167.88 & 99.67 & \\
Total & 217188.96 & 211 & & & \\
\hline
\end{tabular}

The means of student responses to each FLCAS item divided into three anxiety levels are displayed in Table 4. As each item in the anxiety questionnaire was built on a six-point scale, it is reasonable to suspect that any item scoring at or above 3.5 would indicate a certain level of foreign language anxiety. The current findings revealed that eleven means of the individual items were above $3.5(38 \%)$ and the average item score for the full sample was 3.45 , which can be rounded up to 3.50 (see Table 4). As all of the 29 items had an average item score above 3.0, the findings indicated that overall, the elementary school children tended to feel a mild level of anxiety about learning a foreign language in the classroom. The findings generally supported Chan and Wu's (2004) study on the anxiety level of fifth graders around the capital city of Taiwan; however, the sample in their study had a more obvious level of anxiety than students in the current study. Various factors, e.g., regional differences, different competition from peers, and different expectations from teachers and parents, may all account for this inconsistency.

Similarly, compared with the average item score for the university students in Liu's (2012) study, 4.23, the average item score for the elementary school children in the current research was apparently lower. The majority of the participants in Liu's study, though, should have been through years of examination-oriented instruction prior to entering university. Further, they are required to reach an aptitude threshold based on their English proficiency before they graduate from the school. Thus, it is reasonable to expect a higher level of anxiety from 
these students than from those in the current study for whom an English course is not usually as important as it is for students in higher grade levels.

Among the 29 items, items $10($ mean $=4.07)$ and 21 (mean $=4.06)$ had the highest scores for the full sample. In addition to item 7 (thinking that other students are better at English than oneself), items 10 and 21 were also on the top five lists for students in the low- or average-anxiety levels (see Table 5). While item 10 examined learners' anxiety over inadequate performance in the language classroom (Cheng, Hortwiz, \& Schallert, 1999), item 21 mainly assessed student fear of negative evaluation by the others (Horwitz, Horwitz, \& Cope, 1986).

Table 4. Means of student responses to FLCAS items divided into three different anxiety levels

\begin{tabular}{|c|c|c|c|c|}
\hline Item No. & Low-Anxiety & Mid-Anxiety & High-Anxiety & Full Sample \\
\hline 1 & 1.86 & 3.46 & 4.86 & 3.45 \\
\hline 2 & 2.86 & 3.68 & 4.32 & 3.66 \\
\hline 3 & 1.72 & 3.86 & 5.09 & 3.68 \\
\hline 4 & 1.82 & 3.27 & 4.80 & 3.33 \\
\hline 5 & 2.68 & 3.69 & 4.00 & 3.53 \\
\hline 6 & 2.06 & 3.31 & 4.30 & 3.28 \\
\hline 7 & 2.56 & 3.92 & 5.36 & 3.98 \\
\hline 8 & 2.24 & 3.09 & 3.93 & 3.11 \\
\hline 9 & 1.90 & 3.63 & 5.27 & 3.66 \\
\hline 10 & 2.88 & 4.02 & 5.21 & 4.07 \\
\hline 11 & 1.56 & 3.09 & 4.29 & 3.05 \\
\hline 12 & 1.80 & 3.50 & 4.93 & 3.48 \\
\hline 13 & 1.54 & 3.17 & 4.34 & 3.09 \\
\hline 14 & 1.98 & 3.34 & 5.14 & 3.50 \\
\hline 15 & 1.56 & 3.18 & 4.61 & 3.17 \\
\hline 16 & 2.24 & 3.31 & 4.48 & 3.37 \\
\hline 17 & 1.60 & 3.14 & 4.84 & 3.23 \\
\hline 18 & 1.94 & 4.18 & 5.43 & 3.98 \\
\hline 10 & 1.58 & 3.12 & 4.75 & 3.19 \\
\hline 20 & 2.52 & 3.32 & 3.68 & 3.23 \\
\hline 21 & 2.56 & 3.92 & 5.63 & 4.05 \\
\hline 22 & 1.36 & 3.50 & 5.14 & 3.43 \\
\hline 23 & 1.44 & 3.25 & 5.29 & 3.36 \\
\hline 24 & 1.36 & 2.97 & 5.16 & 3.17 \\
\hline 25 & 1.26 & 3.23 & 5.02 & 3.24 \\
\hline 26 & 2.08 & 3.16 & 4.43 & 3.24 \\
\hline 27 & 2.02 & 3.42 & 4.96 & 3.50 \\
\hline 28 & 1.40 & 3.16 & 5.02 & 3.24 \\
\hline 29 & 2.06 & 3.77 & 5.20 & 3.75 \\
\hline Average & 1.95 & 3.44 & 4.81 & 3.45 \\
\hline
\end{tabular}

Note. Mid-Anxiety $=$ Medium-Anxiety

For students in the high-anxiety group, almost all of the items scores were above 4.0, with only two exceptions (items 8 and 20). Thirteen items (45\%) out of the 29 items had item scores above 5.0. The average item score for the entire group was also above 5.0, indicating that these students did experience a certain amount of anxiety in the language classroom. The top five items that had the highest anxiety scores among students in the high-anxiety level were items 21, 18, 7, 23, and 9. According to Horwitz et al. (1986), the high scores on items 21,7 , and 23 reflect student fear of negative evaluation by their teachers or peers. Cheng et al. (1999) found that the high scores on item 21 as well as on items 7 and 9 were also indicative of student low self-confidence in speaking a foreign language. As to item 18, student responses indicated worry over incompetent classroom performance. It should be noted that both items 7 and 21 were identified as having the highest scores among 
students in all three anxiety levels.

Table 5. Items with the Highest Anxiety Item Scores for Students in Each Anxiety Level

\begin{tabular}{|c|c|c|c|c|c|}
\hline Anxiety Level & No. & Item Description & Ranking & Mean & SD \\
\hline \multirow[t]{5}{*}{ Low-Anxiety } & 10 & I worry that I will fail my English course. & 1 & 2.88 & 2.16 \\
\hline & 2 & $\begin{array}{l}\text { I don't worry about making mistakes in my English class. } \\
\text { (reverse-worded) }\end{array}$ & 2 & 2.86 & 2.10 \\
\hline & 5 & $\begin{array}{l}\text { It wouldn't bother me at all to take more English classes. } \\
\text { (reverse-worded) }\end{array}$ & 3 & 2.68 & 2.11 \\
\hline & 7 & $\begin{array}{l}\text { I always think that my classmates are better at English than } \\
\text { I am. }\end{array}$ & 4 & 2.56 & 1.76 \\
\hline & 21 & $\begin{array}{l}\text { I always feel that the other students speak English better } \\
\text { than I do. }\end{array}$ & 4 & 2.56 & 1.81 \\
\hline \multirow[t]{5}{*}{ Mid-Anxiety } & 18 & $\begin{array}{l}\text { I can feel my heart pounding when I am going to be called } \\
\text { on in my English class. }\end{array}$ & 1 & 4.18 & 1.46 \\
\hline & 10 & I worry that I will fail my English course. & 2 & 4.02 & 1.82 \\
\hline & 21 & $\begin{array}{l}\text { I always feel that the other students speak English better } \\
\text { than I do. }\end{array}$ & 3 & 3.92 & 1.65 \\
\hline & 7 & $\begin{array}{l}\text { I always think that my classmates are better at English than } \\
\text { I am. }\end{array}$ & 4 & 3.92 & 1.58 \\
\hline & 3 & $\begin{array}{l}\text { I feel uneasy when I know that I'm going to be called on in } \\
\text { my English class. }\end{array}$ & 5 & 3.86 & 1.42 \\
\hline \multirow[t]{5}{*}{ High-Anxiety } & 21 & $\begin{array}{l}\text { I always feel that the other students speak English better } \\
\text { than I do. }\end{array}$ & 1 & 5.63 & 1.02 \\
\hline & 18 & $\begin{array}{l}\text { I can feel my heart pounding when I am going to be called } \\
\text { on in my English class. }\end{array}$ & 2 & 5.43 & 0.91 \\
\hline & 7 & $\begin{array}{l}\text { I always think that my classmates are better at English than } \\
\text { I am. }\end{array}$ & 3 & 5.36 & 1.23 \\
\hline & 23 & $\begin{array}{l}\text { My English class moves so quickly that I worry about } \\
\text { being left behind. }\end{array}$ & 4 & 5.29 & 1.06 \\
\hline & 9 & $\begin{array}{l}\text { I panick when I have to speak without preparation in my } \\
\text { English class. }\end{array}$ & 5 & 5.27 & 1.18 \\
\hline \multirow[t]{5}{*}{ Full Sample } & 10 & I worry that I will fail my English course. & 1 & 4.07 & 1.98 \\
\hline & 21 & $\begin{array}{l}\text { I always feel that the other students speak English better } \\
\text { than I do. }\end{array}$ & 2 & 4.05 & 1.89 \\
\hline & 18 & $\begin{array}{l}\text { I can feel my heart pounding when I am going to be called } \\
\text { on in my English class. }\end{array}$ & 3 & 3.98 & 1.81 \\
\hline & 7 & $\begin{array}{l}\text { I always think that my classmates are better at English than } \\
\text { I am. }\end{array}$ & 4 & 3.98 & 1.83 \\
\hline & 29 & $\begin{array}{l}\text { I get nervous when my English teacher asks me questions } \\
\text { that I am not able to prepare fore in advance. }\end{array}$ & 5 & 3.75 & 1.88 \\
\hline
\end{tabular}

The means of LLSU divided into three anxiety levels are displayed in Table 6. The findings indicate that strategy use frequency decreased as anxiety level increased. The low-anxiety students used metacognitive strategies most frequently, followed by social and cognitive strategies. Metacognitive strategies were also the most often used type of strategies by students in the average-anxiety level, followed by affective and social strategies. As to students in the high-anxiety group, affective strategies were used most often, followed by metacognitive and cognitive strategies.

It should be noted that the LLSU frequency for students in all anxiety levels was mostly in the medium-use range according to Oxford's (1990) evaluation standard. The only two categories that had LLSU in the high-use range were metacognitive or social strategy categories for low-anxiety students. The findings concerning the use of metaconigitive strategies were consistent with Liu's (2013) results that metacognitive strategies were generally found to be the first or second most frequently used strategies by university students, regardless of their level of anxiety. However, one inconsistency occurred regarding the use of social strategies. As social strategies was in 
the high-use range by low-anxiety students and the third most used by average-anxiety students in the present study, they were found to be the least frequently used strategies by the university students in Liu's study, regardless of student anxiety level.

Table 6. Means of LLSU by students divided by different levels of language anxiety

\begin{tabular}{lcccccc}
\hline \multirow{2}{*}{ Strategy Category } & \multicolumn{2}{c}{ Low-Anxiety } & \multicolumn{2}{c}{ Mid-Anxiety } & \multicolumn{2}{c}{ High-Anxiety } \\
\cline { 2 - 7 } & Rank Order & Mean & Rank Order & Mean & Rank Order & Mean \\
\hline Memory & 5 & 3.06 & 6 & 2.65 & 6 & 2.47 \\
Cognitive & 3 & 3.43 & 4 & 2.82 & 3 & 2.72 \\
Compensation & 6 & 3.05 & 5 & 2.68 & 4 & 2.59 \\
Metacognitive & 1 & 3.74 & 1 & 3.02 & 2 & 2.87 \\
Affective & 4 & 3.30 & 2 & 2.95 & 1 & 3.01 \\
Social & 2 & 3.59 & 3 & 2.88 & 5 & 2.57 \\
Overall & & 3.35 & & 2.83 & & 2.71 \\
\hline
\end{tabular}

The Pearson correlations computed for the variables in the present study are reported in Table 7. Consistent with the previous finding of Liu (2013), a significant negative correlation $(r=-.29, p<.01)$ was identified between the two major variables, overall strategy use and language anxiety, only the relationship was apparently stronger for the Taiwanese university students in Liu's study. Students who had greater strategy use tended to be less likely to feel anxiety. In addition, MI was found to have a significant association with both LLSU and anxiety; however, its relationship with LLSU (.50) was much stronger than that with anxiety (-.15). The positive relationship between MI and LLSU matched the finding in Akbari and Hosseini's (2008) investigation that the two variables had a correlation coefficient of .46. All six strategy categories in the present study were also found to have significant correlations with MI, ranging from .37 to .47 .

Table 7. Pearson correlations between strategy use, language anxiety, length of taking extracurricular English lessons, and length of English study, and multiple intelligences

\begin{tabular}{|c|c|c|c|c|c|c|c|c|c|c|c|}
\hline Variable & 1 & 2 & 3 & 4 & 5 & 6 & 7 & 8 & 9 & 10 & 11 \\
\hline 1. Strategy & - & & & & & & & & & & \\
\hline 2. Memory & $.879 * *$ & - & & & & & & & & & \\
\hline 3. Cognitive & $.923 * *$ & $.783 * *$ & - & & & & & & & & \\
\hline 4. Compensation & $.768^{* *}$ & $.644 * *$ & $.627^{* *}$ & - & & & & & & & \\
\hline 5. Metacognitive & $.891 * *$ & $.702 * *$ & $.809 * *$ & $.611 * *$ & - & & & & & & \\
\hline 6. Affective & $.841^{* *}$ & $.669 * *$ & $.708 * *$ & $.575^{* *}$ & $.697 * *$ & - & & & & & \\
\hline 7. Social & $.858 * *$ & $.683^{* *}$ & $.754 * *$ & $.615^{* *}$ & $.770^{* *}$ & $.706^{* *}$ & - & & & & \\
\hline 8. Anxiety & $-.289 * *$ & $-.257 * *$ & $-.286^{* *}$ & $-.200^{* *}$ & $-.301 * *$ & -.117 & $-.346^{* *}$ & - & & & \\
\hline 9. Length 1 & $.187^{*}$ & .118 & $.227 * *$ & .085 & $.235^{* *}$ & .111 & $.167^{*}$ & $-.169 *$ & - & & \\
\hline 10. Length 2 & .106 & .062 & .109 & .010 & .132 & .099 & .137 & $-.279 *$ & $.701^{* *}$ & - & \\
\hline 11. MI & $.502 * *$ & $.369^{* *}$ & $.469 * *$ & $.380 * *$ & $.458 * *$ & $.472 * *$ & $.459 * *$ & $-.150 *$ & -.004 & .041 & - \\
\hline
\end{tabular}

Note. Strategy $=$ Overall strategy use; Anxiety = Language anxiety; Actual = Actual language proficiency; Length 1 = Length of taking extracurricular English lessons; Length 2 = Length of English study; MI = Multiple Intelligences.

$* p<.05 ; * * p<.01$

As to the young students' English learning experience, length of taking extracurricular English lessons was found to have significant correlations with both overall strategy use $(r=.19)$ and language anxiety $(r=-.17)$. Although the correlations were relatively low, the results still suggest that students who had more experience in taking English lessons outside the class were more likely to use learning strategies and also, they were less likely to feel anxiety. Similarly, length of English study was found to be negatively associated with language anxiety $(r$ $=-.18$ ), although its association with LLSU was insignificant. The two variables related to English learning experience, however, were found to have a non-significant relationship with MI.

It should be noted that among the six strategy categories, strategies in the social category had the strongest 
negative relationship with language anxiety (-.35), followed by metacognitive (-.30) and cognitive categories (-.29). The current findings generally support MacIntyre and Noels's (1996) findings that social strategies have the highest correlation with strategy use, followed by cognitivie and metacognitive strategies. According to Ehrman, Leaver, and Oxford (2003), students who apply social strategies may be more likely to interact with others when they learned. For example, they ask for help when encountering difficulties in a language task or they talk with a native speaker to practice communicating in the target language. The current results indicated that for these young learners, applying these types of learning strategies may help them feel less pressure or anxiety about inadequate language performance or negative evaluation from peers.

Finally, to further examine the relationships between anxiety, MI, and LLSU, a regression analysis using a stepwise method was performed on the data with LLSU as the criterion variable (Table 8). The results revealed that a combination of the two learner variables, MI and anxiety, can predict nearly $30 \%$ of the variance in strategy use by the elementary school students.

Table 8. Results of the multiple regression model for predicting learning strategy use

\begin{tabular}{llllll}
\hline Variable & $\begin{array}{l}\text { Regression } \\
\text { Coefficient }\end{array}$ & $\begin{array}{l}\text { Standard } \\
\text { error }\end{array}$ & Beta & $t$ & $p$ \\
\hline (Constant) & 45.17 & 9.78 & & 4.62 & $.000^{* *}$ \\
MI & .39 & .05 & .47 & 8.01 & $.000^{* *}$ \\
Anxiety & -.18 & .05 & -.22 & -3.72 & $.000^{* *}$ \\
\hline
\end{tabular}

Model: $\mathrm{R}^{2}=.546 ;$ Adjusted $\mathrm{R}^{2}=.298 ; \mathrm{F}(2,209)=44.45$;

$* * p<.01$

\section{Conclusion and Implications}

The major research findings of the present study reveal that the elementary school children generally felt a mild level of anxiety in the EFL context, although some did feel stronger levels of anxiety in the foreign language classroom. The major research findings are described in the following.

First, for at least a quarter of students, the inclination for them to feel anxious about foreign language learning was quite obvious. These students tended to be most anxious when (1) feeling that their peers had better English performance than they did, (2) being called on to speak in the target language, and (3) worrying about being left behind the English class. Overall, inadequate language performance and fear of being evaluated negatively by others were most likely to induce anxiety among the young learners.

Second, LLSU increased as anxiety level decreased. The low-anxiety students used metacognitive strategies most frequently, followed by social and cognitive strategies. Metacognitive strategies were also the most often used type of strategies by students in the mid-anxiety level, followed by affective and social strategies. It is interesting to find that affective strategies were used most often by students in the high-anxiety group, followed by metacognitive and cognitive strategies.

Third, the correlations between the two variables related to language learning experience and the other two major variables, LLSU and anxiety, were mostly negative and significant, but in the low-level range. The results revealed a higher, negative, and significant correlation between LLSU and foreign language anxiety. Students who had greater LLSU were likely to experience a lower level of anxiety in the language classroom. Among the six strategy categories, language anxiety was most strongly related to strategies in the social category, followed by metacognitive and cognitive categories. While variables related to learning experience had no significant relationship with MI, both LLSU and language anxiety were significantly correlated with MI, the former being much stronger than the latter. A combination of the two learner variables, MI and anxiety, could predict nearly $30 \%$ of the variance in strategy use by the elementary school students.

The current findings suggested a few implications. First, encouraging strategy use can not only be beneficial to the enhancement of higher motivation (Oxford \& Nyikos, 1989) and language proficiency (Green \& Oxford, 1995; Griffiths, 2003), but can also help relieve language anxiety among the EFL students. Compared with taking extracurricular lesson outside the class, LLSU appeared to play a more important role in minimizing language anxiety. Teachers should identify those who are susceptible to a higher level of anxiety and provide them with more opportunities to practice the use of learning strategies. 
Second, the use of social strategies should be encouraged among EFL learners as the findings indicated that strategies in this category had the strongest negative relationship with language anxiety. Due to the limited opportunity to practice the target language in the EFL environment and perhaps the communication apprehension pointed out by Horwitz et al. (1986), social strategies were often listed as one of the two or three least used types of strategies by researchers (Lan \& Oxford, 2003; Liu, 2013; Sheu, 2009) in the EFL context. As mentioned previously, application of social strategies enables students to interact with others more often (Ehrman, Leaver, \& Oxford, 2003; Oxford, 2003), e.g., by asking for help, asking for clarification, or talking with a native speaker to practice conversation in the target language. More interaction with others can help relieve feelings of frustration or anxiety about inadequate performance or worry over negative evaluation to some degree.

Third, among the different categories of learning strategies, the use of metacognitive strategies should be strongly recommended and promoted in the language classroom. According to Goh \& Foong (1997), practicing the use of metacognitive strategies may enable learners to plan, monitor, and self-regulate their own learning. As found in the present study, learners with low anxiety employed metacognitive strategies most frequently, followed by social strategies. Many researchers such as and Mochizuki (1999) and Wu (2008) pointed out that high proficiency language learners used metacognitive strategies more frequently. MacIntyre and Noels (1996) concluded that metacognitive strategies had the strongest link with motivation. Chang (2003) also revealed that metacognitive strategies have a stronger correlation with learner motivation than other types of strategies.

Finally, as MI was significantly related to LLSU, the application of the MI theory in language instruction can contribute to the effectiveness of student learning in the classroom and thus should be more widely embraced. Through increasing awareness and application of the MI concept, the effectiveness of learning strategies can be enhanced. Teele (1994) considered the MI theory to be "the key to providing quality instruction" in the classroom (p. 141). Teaching on the basis of the MI theory enables teachers to help students reach their potential and become more actively involved in the learning process through their dominant intelligences (Teele, 1994).

To sum up, students should be encouraged to explore different learning strategies and identify the most appropriate ones for themselves at an earlier age. For those who are prone to feel language anxiety, social and metacognitive strategies are the most strongly recommended for use. It is imperative that language instructors create a positive learning environment which enables students to maximize their potential and become more effective learners.

\section{References}

Aida, Y. (1994). Examination of Horwitz, Horwitz, and Cope's construct of foreign language anxiety: The case of students of Japanese. The Modern Language Journal, 78(2), 155-168. http://dx.doi.org/10.1111/j.1540-4781.1994.tb02026.x

Akbari, R., \& Hosseini, K. (2008). Multiple intelligences and language learning strategies: Investigating possible relations. System, 36, 141-155. http://dx.doi.org/10.1016/j.system.2007.09.008

Baker, W., \& Boonkit, K. (2004). Learning strategies in reading and writing: EAP contexts. RELC, 35(3), 299-328. http://dx.doi.org/10.1177/0033688205052143

Bremner, S. (1998). Language learning strategies and language proficiency: Investigating the relationship in Hong Kong. Asian Pacific Journal of Language in Education, 1(2), 490-514.

Bremner, S. (1999). Language learning strategies and language proficiency: Investigating the relationship in Hong Kong. Canadian Modern Language Review, 55(4), 490-514. http://dx.doi.org/10.3138/cmlr.55.4.490

Campbell, B., Campbell, L., \& Dickinson, D. (1999). Teaching and learning through multiple intelligences. Needham Heights, MA: Allyn \& Bacon.

Chamot, A. U. (2005). Language learning strategy instruction: Current issues and research. Annual Review of Applied Linguistics, 25, 112-130. http://dx.doi.org/10.1017/S0267190505000061

Chamot, A. U., \& El-Dinary, P. B. (1999). Children's learning strategies in language immersion classrooms. The Modern Language Journal, 83(3), 319-338. http://dx.doi.org/10.1111/0026-7902.00025

Chan, D. Y. C., \& Wu, G. C. (2004). A study of foreign language anxiety of EFL elementary school students in Taipei county. Journal of National Taipei Teachers College, 17(2), 287-320.

Chang, C.-Y. (2003). The effects of language learning motivation on the use of language learning strategies among EFL learners at technological universities and colleges in Taiwan (Unpublished doctoral dissertation, Spalding University). 
Chen, T. Y., \& Chang, G. B. Y. (2004). The relationship between foreign language anxiety and learning difficulties. Foreign Language Annals, 37(2), 279-287. http://dx.doi.org/10.1111/j.1944-9720.2004.tb02200.x

Cheng, Y.-S. (2005). EFL learners' listening comprehension anxiety. English Teaching \& Learning, 29(3), 25-44.

Cheng, Y.-S., Horwitz, E. K., \& Schallert, D. L. (1999). Language anxiety: Differentiating writing and speaking components. Language Learning, 49(3), 417-446. http://dx.doi.org/10.1111/0023-8333.00095

Ehrman, M. E., Leaver, B. L., \& Oxford, R. L. (2003). A brief overview of individual differences in second language learning. System, 31, 313-330. http://dx.doi.org/10.1016/S0346-251X(03)00045-9

Ehrman, M. E., \& Oxford, R. L. (1990). Adult language learning styles and strategies in an intensive training setting. Modern Language Journal, 74(3), 311-327. http://dx.doi.org/10.1111/j.1540-4781.1990.tb01069.x

Gardner, H. (1983). Frames of mind: The theory of multiple intelligences. New York: Basic Books.

Gardner, H. (1995). Reflections on multiple intelligences: Myths and messages. Phi Delta Kappan, 77(3), 198-209.

Gardner, R. C. (1985). Social psychology and second language learning. Rowley, MA: Newbury House.

Gardner, R. C. (2000). Correlation, causation, motivation, and second language acquisition. Canadian Psychology, 41, 10-24. http://dx.doi.org/10.1037/h0086854

Gardner, R. C., \& MacIntyre, P. D. (1991). An instrumental motivation in language study: Who said it isn't effective? Studies in Second Language Acquisition, 13(1), 39-53. http://dx.doi.org/10.1017/S0272263100009724

Gardner, R. C., \& MacIntyre, P. D. (1993). A student's contributions to second-language learning. Part II: Affective variables. Language Teaching, 26, 1-11. http://dx.doi.org/10.1017/S0261444800000045

Goh, C. C. M., \& Foong, K. P. (1997). Chinese ESL students' learning strategies: A look at frequency, proficiency, and gender. Hong Kong Journal of Applied Linguistics, 2(1), 39-53.

Green, J. M., \& Oxford, R. L. (1995). A closer look at learning strategies, L2 proficiency, and gender. TESOL Quarterly, 29(2), 261-297. http://dx.doi.org/10.2307/3587625

Griffiths, C. (2003). Patterns of language learning strategy use. System, 31, 367-383. http://dx.doi.org/10.1016/S0346-251X(03)00048-4

Haley, M. H. (2004). Learner-centered instruction and the theory of multiple intelligences with second language learners. Teachers College Record, 106(1), 163-180. http://dx.doi.org/10.1111/j.1467-9620.2004.00326.x

Hong-Nam, K., \& Leavell, A. G. (2006). Language learning strategy use of ESL students in an intensive English learning context. System, 34(3), 399-415. http://dx.doi.org/10.1016/j.system.2006.02.002

Horwitz, E. K., Horwitz, M. B., \& Cope, J. (1986). Foreign language classroom anxiety. The Modern Language Journal, 70(2), 125-132. http://dx.doi.org/10.1111/j.1540-4781.1986.tb05256.x

Hsieh, C. C. (2001). The relationships between multiple intelligences, thinking styles, and critical-thinking abilities of the fifth-and sixth grade students (Unpublished master's thesis, National Sun Yat-Sen University, Kaohsiung, Taiwan).

Kim, J.-H. (2000). Foreign language listening anxiety: A study of Korean students learning English (Unpublished doctoral dissertation, University of Texas, Austin).

Lai, Y.-C. (2009). Language learning strategy use and English proficiency of university freshmen in Taiwan. TESOL Quarterly, 43(2), 255-280.

Lan, R. L. (2005). Language learning strategy profiles of EFL elementary school students in Taiwan (Unpublished doctoral dissertation, University of Maryland).

Lan, R., \& Oxford, R. L. (2003). Language learning strategy profiles of elementary school students in Taiwan. IRAL, 41, 339-379. http://dx.doi.org/10.1515/iral.2003.016

Littlewood, W. (2001). Students' attitudes to classroom English learning: A cross-cultural study. Language Teaching Research, 5(1), 3-28.

Liu, H. J. (2012). Understanding EFL undergraduate anxiety in relation to motivation, autonomy, and language proficiency. Electronic Journal of Foreign Language Teaching, 9(1), 123-139.

Liu, H. J. (2013). Effects of foreign language anxiety and perceived competence on learning strategy use. 
International Journal of English Linguistics, 3(3), 76-87. http://dx.doi.org/10.5539/ijel.v3n3p76

Liu, H. J., \& Chang, C. H. (2013). A study on language learning strategy use and its relation to academic self-concept: The case of EFL students in Taiwan. Journal of Language Teaching and Research, 4(2), 260-268. http://dx.doi.org/10.4304/jltr.4.2.260-268

Macaro, E. (2006). Strategies for language learning and for language use: Revising the theoretical Framework. The Modern Language Journal, 90(3), 320-337. http://dx.doi.org/10.1111/j.1540-4781.2006.00425.x

MacIntyre, P. D. (1999). Language anxiety: A review of the research for language teachers. In D. J. Young (Ed.), Affect in foreign language and second language leanring: A practical guide to creating a low-anxiety classroom atmosphere. Boston: McGraw-Hill College.

MacIntyre, P. D., \& Gardner, R. C. (1991). Methods and results in the study of anxiety and language learning: A review of the literature. Language Learning, 41(1), 85-117. http://dx.doi.org/10.1111/j.1467-1770.1991.tb00677.x

MacIntyre, P. D., \& Noels, K. A. (1996). Using social-psychological variables to predict the use of language learning strategies. Foreign Language Annals, 29(3), 373-386. http://dx.doi.org/10.1111/j.1944-9720.1996.tb01249.x

MacIntyre, P. D., Noels, K. A., \& Clément, R. (1997). Biases in self-ratings of second language proficiency: The role of language anxiety. Language Learning, 47(2), 265-287. http://dx.doi.org/10.1111/0023-8333.81997008

Mochizuki, A. (1999). Language learning strategies used by Japanese university students. RELC Journal, 30(2), 101-113. http://dx.doi.org/10.1177/003368829903000206

Onwuegbuzie, A. J., Bailey, P., \& Daley, C. E. (1997). Foreign language anxiety among college students. Paper presented at the annual conference of the Mid-South Educational Research Association, Memphis, TN. (ERIC Document Reproduction Service No. ED 415 713)

Onwuegbuzie, A. J., Bailey, P., \& Daley, C. E. (1999). Factors associated with foreign language anxiety. Applied Psycholinguistics, 20, 217-239. http://dx.doi.org/10.1017/S0142716499002039

Oxford, R. L. (1990). Language learning strategies: What every teacher should know. Boston, MA: Heinle \& Heinle.

Oxford, R. L. (2003). Language learning styles and strategies: An overview. Retrieved June 22, 2011, from http://web.ntpu.edu.tw/ language/workshop/read2.pdf

Oxford, R. L., \& Anderson, N. J. (1995). A cross-cultural view of learning styles. Language Teaching, 28, 201-215. http://dx.doi.org/10.1017/S0261444800000446

Oxford, R. L., \& Ehrman, M. E. (1995). Adults' language learning strategies in an intensive foreign language program in the United States. System, 23(3), 359-386. http://dx.doi.org/10.1016/0346-251X(95)00023-D

Oxford, R. L., \& Nyikos, M. (1989). Variables affecting choice of language learning strategies by university students. Modern Language Journal, 73(2), 291-300. http://dx.doi.org/10.1111/j.1540-4781.1989.tb06367.x

Park, G.-P. (1997). Language learning strategies and English proficiency in Korean university students. Foreign Language Annals, 30(2), 211-221. http://dx.doi.org/10.1111/j.1944-9720.1997.tb02343.x

Park, Y. (1999). An analysis of interrelationship among language learning strategies, learning styles and learner variables of university students. English Teaching, 54(4), 281-308.

Peacock, M., \& Ho, B. (2003). Student language learning strategies across eight disciplines. International Journal of Applied Linguistics, 13(2), 179-195. http://dx.doi.org/10.1111/1473-4192.00043

Phillips, E. M. (1992). The effects of language anxiety on students' oral test performance and attitudes. The Modern Language Journal, 76(1), 14-26. http://dx.doi.org/10.1111/j.1540-4781.1992.tb02573.x

Qingquan, N., Chatupote, M., \& Teo, A. (2008). A deep look into learning strategy use by successful and unsuccessful students in the Chinese EFL learning Context. Regional Language Center Journal, 39(3), 338-358.

Reid, J. M. (1987). The learning style preferences of ESL students. TESOL Quarterly, 21(1), 87-111. http://dx.doi.org/10.2307/3586356

Saito, Y., Horwitz, E. K., \& Garza, T. J. (1999). Foreign language reading anxiety. The Modern Language Journal, 83(2), 202-218. http://dx.doi.org/10.1111/0026-7902.00016 
Saito, Y., \& Samimy, K. K. (1996). Foreign language anxiety and language performance: A study of learner anxiety in beginning, intermediate, and advanced-level college students of Japanese. Foreign Language Annals, 29(2), 239-251. http://dx.doi.org/10.1111/j.1944-9720.1996.tb02330.x

Sheu, C.-M. (2009). An investigation into English Learning Strategies of Ability-Grouped Freshman Students in a National Technological University. Studies in English Language and Literature, 23, 23-39.

Sparks, R., \& Ganschow, L. (2001). Aptitude for learning a foreign language. Annual Review of Applied Linguistics, 21, 90-111. http://dx.doi.org/10.1017/S026719050100006X

$\mathrm{Su}$, M. H. (2003). An investigation of Taiwanese grade 5-6 students' EFL language learning strategies and language learning experience. The Journal of Educational Science, 3(1), 138-177.

$\mathrm{Su}, \mathrm{M}$. M. (2005). A study of EFL technological and vocational college students' language learning strategies and their self-perceived English proficiency. Electronic Journal of Foreign Language Teaching, 2(1), 44-56.

Teele, S. (1994). The relationship of multiple intelligences to the instructional process (Unpublished doctoral dissertation, University of California, Riverside).

Vogely, A. J. (1998). Listening comprehension anxiety: Students' reported sources and solutions. Foreign Language Annals, 31(1), 67-80. http://dx.doi.org/10.1111/j.1944-9720.1998.tb01333.x

Wharton, G. (2000). Language learning strategy use of bilingual foreign language learners in Singapore. Language Learning, 50(2), 203-243. http://dx.doi.org/10.1111/0023-8333.00117

Wu, Y.-L. (2008). Language learning strategies used by students at different proficiency levels. Asian EFL Journal, 10(4), 75-95.

Yan, J. X., \& Horwitz, E. K. (2008). Learners' perceptions of how anxiety interacts with personal and instructional factors to influence their achievement in English: A qualitative analysis of EFL learners in China. Language Learning, 58(1), 151-183. http://dx.doi.org/10.1111/j.1467-9922.2007.00437.x

Young, D. J. (1990). An investigation of students' perspectives on anxiety and speaking. Foreign Language Annals, 23(6), 539-553. http://dx.doi.org/10.1111/j.1944-9720.1990.tb00424.x

Young, D. J. (1991). Creating a low-anxiety classroom environment: What does language anxiety research $\begin{array}{lllll}\text { suggest? } & \text { The } & \text { 426-439. }\end{array}$ http://dx.doi.org/10.1111/j.1540-4781.1991.tb05378.x

\section{Copyrights}

Copyright for this article is retained by the author(s), with first publication rights granted to the journal.

This is an open-access article distributed under the terms and conditions of the Creative Commons Attribution license (http://creativecommons.org/licenses/by/3.0/). 